\title{
Phillip Deen* \\ Was Dave Chappelle Morally Obliged to Leave Comedy? On the Limits of Consequentialism
}

\begin{abstract}
Dave Chappelle took an extended leave from comedy for moral reasons. I argue that, while he had every right to leave comedy because of his moral concerns, he was not obliged to do so. To make this case, I present Chappelle's argument that the potential negative consequences of his racial humor obliged him to leave. Next, I argue against Chappelle's argument about avoidable harms as the harms are not his responsibility, he was not being negligent, and the benefits of his humor outweigh the harms. I also argue in support of the intuition that another's failure of comprehension or moral character, even if that failure will predictably result in harms to others, should not convert moral acts into immoral ones.
\end{abstract}

Keywords: Chappelle, humor, comedy, race, consequentialism

\section{Introduction}

In 2014, Dave Chappelle returned to comedy after almost ten years of near absence. He famously left both stand-up and an astounding \$50M contract for his eponymous show on Comedy Central because he faced a moral crisis. He worried that his humor, which mined racist stereotypes in order to critique them and to make wry observations about contemporary America, was actually perpetuating those stereotypes. It is not easy to imagine walking away from the wealth, fame, and fulfillment that Chappelle had received from his comedy career. To do so because of deeply held moral beliefs is truly admirable. However, it was not required.

I argue that, while he had every right to leave comedy because of his moral concerns, he was not obliged to do so. To make this case, I will present Chappelle's argument for leaving comedy. Next, I will argue against Chappelle's argument against avoidable harms as the harms are not his responsibility, he was not being negligent, and the benefits of his humor outweigh the harms. I also argue in support of the intuition that another's failure of comprehension or moral char-

* University of New Hampshire; phillip.deen@unh.edu

https://doi.org/10.1515/2698-718X-011 
acter, even if that failure will predictably result in harms to others, should not convert moral acts into immoral ones.

Beyond addressing Chappelle's narrow case, this article has a broader goal. Ethical criticism of comedy has often focused on the character of the people who laugh. Being amused by morally suspect comedy is said to reveal a morally suspect character. However, other critics assert that, irrespective of the comedian's intent, it is morally wrong to tell certain jokes because of their consequences. By discussing the limits of Chappelle's argument for leaving standup, we can also see the limits of a purely consequentialist approach to the ethical criticism of comedy. ${ }^{1}$

\section{Chappelle's Argument for Leaving}

Chappelle stated many reasons for leaving comedy, but the main ones were essentially moral. ${ }^{2}$ I will quickly state two before concentrating on a third. First, it was a matter of self-care. Having reached great heights in pop culture, he was under enormous stress. The more success he has had in television, the less happy he was. For someone who, since high school, had dreamed of "doing a Bobby Fischer" and disappearing from public view, this stress could be damaging. Chappelle also stated that he needed time to mourn his deceased father. When it became too much, he escaped to Africa to take a "sabbatical" where he was largely unknown and others were not making such demands on him.

Second, he believed he was being treated unjustly by the entertainment industry. This concern traces to his past conflicts with it and his fear of exploitation and compromise. His conflicts with the "suits" extended back to his first television pilot for I'm the Man when he was pressured to add an attractive, white female lead, but he refused, and the show was pulled soon after. But even on his wildly successful Chappelle's Show, he felt that he was being pressured into

1 A proviso: Chappelle's comedy about gender and sexuality is far less defensible, particularly in his five Netflix specials since his return to standup, The Age of Spin, Deep in the Heart of Texas, Equanimity, The Bird Revelation, and Sticks and Stones. While certainly worthy of ethical analysis, I have not done so here for reasons of space. The very brief version: His treatment of these topics (particularly trans-people) does not have the nuance and moral purpose that his racial humor does, so it would likely not be protected by this argument.

2 Neal Brennan, co-creator of Chappelle's Show and his former long-time writing partner, supports the moral arguments for leaving, but claimed that Chappelle also left for reasons of ego and control (The Joe Rogan Experience \#114, June 14, 2011). Chappelle also stated that he felt the show was coming at the expense of his standup, though he eventually left both. Since the concern here is ethical, we can set aside other motivations as outside our scope. 
doing things he would not otherwise do. During an interview with Oprah Winfrey, he drew attention to how others profited from his success, garnering their percentage. "You got your own personal problems that get inflamed when this kind of money comes in. I gotta write the show and do the show and I was overwhelmed. I was like, I don't know, it was like all of this was happening deliberately" (Oprah 2006). While conceding that he has paranoid tendencies, he still felt that there was a pattern of exploitation. During an interview on Inside the Actor's Studio before an audience of aspiring artists, Chappelle discussed the intersection of art and corporate interests, saying that it will inevitably break the heart of the artist. He acknowledged that the entertainment industry is one of mutual advantage, but the exchange "should be fair” (Inside the Actor's Studio 2006). ${ }^{3}$ So, as a matter of justice, he had to leave.

However, it is his third argument that is most clearly ethical and richest for philosophical analysis, and the one I will be discussing here. Chappelle left comedy because, while filming a sketch for the upcoming season of his show, a stagehand was laughing seemingly for the wrong reasons, indicating that Chappelle's humor was perpetuating the very problems that he was seeking to overcome. ${ }^{4}$ As he told Oprah Winfrey: "I was doing sketches that were funny, but socially irresponsible." The sketch that caused this epiphany was one of a series about "stereotype pixies."

Though a joke explained is a joke ruined, let's take a moment to explain and ruin this one. The sketch presents Chappelle on a plane afraid to order fried chicken because of how he, a black man, would be perceived by the white passengers. Chappelle is the only African-American passenger on the plane and is surrounded by white people. While it is clear that he prefers the chicken over the fish, he is very aware of a legacy of racist stereotypes about black people and fried chicken-a common element in the Sambo trope of Southern blacks that has been used to ridicule African-Americans and to justify their further oppression. Chappelle's anxiety about how he will be perceived is given form in his imagination as a Sambo stereotype pixie with blackface and a riverboat steward's uniform who shucks and jives to banjo music and demands that the real Chappelle not fight his fate and just order the chicken. Chappelle is shown resisting the stereotype and he makes a public display of his preference for the fish to the white passengers. All the while, the pixie berates him and begs him to live up

3 He makes a similar argument in the last ten minutes of his 2017 special, The Bird Revelation. 4 Rumor has it that the person was not a stagehand but Bill Burr, a celebrated comedian and sometimes member of the Chappelle's Show cast, but the rumor is unsubstantiated. Burr has refused to say it was him, but he has also refused to say it was not him. 
to the stereotype. In short, Chappelle is put in the unfair and awkward position of just wanting to order his preferred meal through the lens of racist perception. ${ }^{5}$

This sketch is itself based on an earlier joke from his 2000 stand-up special Killin' Them Softly in which he discussed his fear of eating chicken in front of white people. In that bit, he discusses confronting racism that is so explicit that, ironically, he misses it. Before he can even place his order in a restaurant in Mississippi, the racist waiter assumes that Chappelle wants the chicken. At first, he thinks that the waiter is just prescient, but he eventually realizes what is actually happening. To which he replies,

All these years, I thought I liked chicken because it was delicious. Turns out I'm genetically predisposed to liking chicken! I got no say in the matter. That guy ruined chicken for me. Now I'm scared to eat it in public. I don't want someone to see me and say something. $<$ mimicking eating a drumstick, then taking up the position of a white observer > "Look at him. He loves it! Just like it said in the encyclopedia! Look how happy he looks!”

Given this, and the content of the Pixie sketch itself, it is clear that Chappelle is making a nuanced, funny comment about the way that African-Americans have to negotiate their self-presentation in a world in which even the simplest of things can reinforce stereotypes.

This is a concern that more privileged people do not have. While everyone has to worry about how they perform themselves in front of others, not everyone has to shoulder this particular burden. Admittedly, the black stereotype pixie is only one in a series that includes a white man whose country-club pixie advises him on how to behave in front of his black friends and restrains his desire for a beautiful black woman, a Hispanic man whose cocaine-using bullfighter pixie encourages him (with an assist from the Spanish-American actress and musician Charo) to get leopard pattern seat covers and a Jesus air freshener for his car, and an Asian man whose pixie sports a traditional Chinese garb, a fu-manchu mustache and buck teeth, eats rice, has L-R confusion, and commits seppuku upon dishonor. Curiously, all four pixies portrayed by Chappelle reflect the anxieties of men, as if women do not worry about self-performance. Further, while all address anxiety about how one is perceived, the white man's anxiety is the only one in which the primary concern is how he will be perceived if he does not act according to his racial stereotype.

5 The sketch was aired as part of the truncated third season on Comedy Central without Chappelle's consent. To their credit, the sketch was framed by an explicit statement of its meaning and much of the episode was an open discussion with the audience about their reaction to it. http://www.cc.com/video-clips/s191yw/chappelle-s-show-stereotype-pixies-black-pixie-uncensored. 
While the black stereotype pixie sketch is a complex and hilarious presentation of how African-American people face the burden of managing their racial representation to others, the stagehand that troubled Chappelle seemed to be laughing along with the racist stereotype being taken seriously. It is conceivable that someone could watch this sketch and miss all the nuance. Instead, their reaction would be to believe that Sambos are just funny, or that they reveal a deeper truth about African-American people and that "it is funny because it's true." This concern was forefront in Chappelle's mind:

Blackface is a very difficult image, but the reason I chose blackface at the time was because this was going to be the visual personification of the "n-word." It was a good spirit or intention behind it. But, what I didn't consider is how many people watch this show and how the way people use television is subjective. So then when I'm on the set and we're finally taping the sketch, somebody on set that was white laughed in such a way-I know the difference between people laughing with me and people laughing at me, and it was the first time I ever got a laugh that I was uncomfortable with. Not just uncomfortable, but like "Should I fire this person?"... I know that all these people who're watching TV, that there's a lot of people who will understand exactly what I'm doing and there's another group of people who are just fans like the kind of people who scream "I'm Rick James, bitch!" at my concerts. They're going to get something completely different. (Oprah 2006)

Chappelle's subversive comedy then runs the ongoing risk of being misinterpreted and of perpetuating the oppressive Sambo image that he had hoped to treat in a far more nuanced way. In short, "When he laughed, it made me uncomfortable. As a matter of fact, that was the last thing I shot before I told myself I gotta take a fucking time out after this. Because my head almost exploded" (Farley 2005).

Chappelle felt responsible to the black community. "I don't want black people to be disappointed in me for putting that out there" (Oprah 2006). Being from both Washington, DC and a liberal, white college town in Ohio, he has always negotiated the white and black communities, welcomed and shunned by both. This is true of him both as a person and as a comedian. Within the broader and whiter comedy community, he felt obligated to represent the black community well-but he also felt the weight of expectations laid on him as a black comedian, as when he regretted his performance on the notoriously raunchy Def Comedy Jam, stating that the demand to be dirty was "limiting everyone" (Zinoman 2017, loc. 253). ${ }^{6}$ And his cross-cultural humor, including having a white writing partner and an early television show about his character's friendship with a white best friend, often did not play well in the black community. He was accused of selling out his people. His sketches about racial representation did

6 See also chapters 2 and 4. 
not begin or end with the stereotype pixie sketch, of course. For example, he mocked the thoroughly socially constructed nature of race in Chappelle's Show's first sketch ever. It was about Clayton Bigsby, the Ku Klux Klan grand wizard who, being blind, was unaware that he was himself black. When introducing the sketch, he revealed that he had shown it to a friend who reacted as if Chappelle had "set black people back." He then shrugged and played it for the studio audience. As Jason Zinoman notes, by the third season featuring the stereotype pixie sketch, "Chappelle had stopped shrugging" (Zinoman 2017, loc. 375). At other times, Chappelle was criticized for representing a black experience that he had not lived. Mike Epps accused him of such: "He don't come from no crackheads on the streets and shit. You can't talk about black people like that and you don't even represent that" (Zinoman 2017, loc. 634-35). In short, Chappelle has had to pay particular attention to how he is perceived by multiple communities, pulled between the demands of each. The issue of racial representation that we find in the stereotype pixie sketch is then one very close to Chappelle's own life. ${ }^{7}$

This concern mystified Neal Brennan, his long-time writing partner: "We'd shoot it, and then at some point he'd start saying, 'This sketch is racist, and I don't want this on the air.' And I was like, 'You like this sketch. What do you mean?' There was this confusing contradictory thing: he was calling his own writing racist" (Farley 2005). But Chappelle's concern did not regard the intention, so it cannot be resolved by noting that he wrote the sketch. No matter the intent behind the sketch or who its source was, the nature of its reception could render it immoral. Chappelle frames this all explicitly as an ethical decision, one of his refusal to compromise his character and of the need to be socially responsible. The price was too high, and he felt an obligation to leave.

Chappelle is not the only comedian to be concerned about how their comedy will be received. For example, Hari Kondabolu, an Indian-American comedian who has been very open about the moral responsibilities of comedians, wrote and starred in the documentary The Problem with Apu about The Simpsons' stereotypical portrayal of Indian-Americans and the ensuing harm done to that community. Explicitly referencing Chappelle, he said:

I don't like the idea that the laugh justifies everything. I don't believe that, because I think there's different kinds of laughs. That's the famous [comedian Dave] Chappelle quandary, right? Are you laughing at me or are you laughing with me? Am I making things better or am I making things worse? I don't think all laughs are equal, because if that is the case, you could

7 For more on Chappelle's concern for authenticity and the difficulty of negotiating racial communities, see Lee 2009 and Yates 2009. For this issue in the context of Chappelle's disappearance, see Amarasingam 2009, particularly 124-26. 
probably put the most racist stuff in the world constantly in things-like the old days-and people would still laugh. (Saraiya 2017) ${ }^{8}$

Similarly, Sarah Silverman worries that her humor will appeal to people who think simple racism is funny (Silverman 2010, 93-94). Even Anthony Jeselnik, who has mastered the art of walking the line of moral unacceptability in his humor, has heard laughs that he did not want and cut jokes because of it (Zinoman 2019)..${ }^{9}$ For any morally decent comedian, the question of whether they are inadvertently doing harm is sure to arise.

To summarize Chappelle's argument: Despite his intention and craft, humor that uses racial stereotypes in order to expose and subvert them may promote or reinforce bigotry among those who inevitably fail to get the joke. Out of a desire not to perpetuate racism and cause further harm, Chappelle then believed he had an obligation to leave comedy.

Chappelle's argument has merit. Laughter can express prejudice. Some have argued that the only way to enjoy racist or otherwise offensive humor is to harbor offensive attitudes and it is certainly possible that that is precisely why the stagehand laughed, which would give Chappelle good reason to be outraged. But this position that finding offensive humor funny necessitates endorsing offensive attitudes is not a sufficient account of offensive humor generally and of this sketch in particular. ${ }^{10}$ Finding offensive humor funny does not necessarily entail that the laugher endorses offensive attitudes, and certainly Chappelle was not endorsing them. However, though laughter does not necessarily entail endorsement, it can. Psychological studies of humor have shown that people find aggressive humor funnier when it targets groups that they dislike. If people are laughing more at his humor when it uses racial stereotypes, then it may draw from an underlying racism.

Second, while humor that uses racial stereotypes has been shown not to cause racist beliefs, it does seem to give people with pre-existing racist beliefs a "permission structure" within which to express and to act upon them. Such humor reduces the barriers to the expression of negative emotions. Racists can say with a joke what it is not permissible to say directly, or the fact that others are laughing about race may lead racists to believe they may express otherwise

8 For a deeper treatment of Kondabolu's humor and his desire to avoid "minstrelry," see Krefting 2014, $196-230$.

9 He also discusses the dangers of his ironic racism in his fourth standup special, Fire in the Maternity Ward.

10 The best known and most discussed presentation of this "Attitudinal Endorsement Argument” is De Sousa 1987. 
unacceptable beliefs. Racial humor has historically been used to reinforce existing racism and further marginalize groups, as humor frequently polices social boundaries. People are informally educated about what is normal or acceptable and what is not by means of playful teasing or harsh ridicule. In racist humor, marginal people are taught to keep in their social lane or suffer social exclusion (or worse) and members of the dominant group are taught that the ongoing exclusion of the ridiculed is justified. So we may not easily dismiss Chappelle's concerns with a breezy, "Don't worry; it's just a joke," as it may give racist people the impression that it is socially acceptable to act on racial stereotypes even if that was neither the intention of the sketch nor even a reasonable interpretation of it (Ferguson and Ford 2008; Ford et. al. 2015).

Third, "Poe's Law" holds that no matter how extreme the irony of a statement is, it will inevitably be taken as literal by someone. Studies of viewer's reactions to All in the Family in the 1970s and The Colbert Report in the 2000s indicate that satire of bigotry will frequently be missed by bigots (Vidmar and Rokeach 1974; LaMarre et al. 2009). ${ }^{11}$ Bizarrely, both prejudiced and non-prejudiced audiences will enjoy the humor to the same degree, but for very different reasons. Prejudiced audiences tend to laugh not because they correctly identify the satire of bigotry, but because they see someone sincerely "telling it like it is." 12

\section{Why Chappelle Was Not Obliged to Leave}

Of course, all other things being equal, we have a moral obligation not to harm innocents, and racism is a clear social evil that we should not deepen. Chappelle's argument then has an intuitive appeal. However, Chappelle was not obliged to leave, even though reasonably predictable harms might result from his racial comedy. My objection originates in an intuition: It seems odd to hold that anyone has an obligation to refrain from inoffensive or genuinely moral actions because of the intellectual or moral failings of others. To what extent should one's virtuous actions be rendered vicious by another's immorality?

11 All in the Family was based on the British program, Till Death Do Us Part, which reportedly misunderstood in much the same way.

12 Brian Gogan has argued that Chappelle's work is particularly vulnerable to this concern because sketches like "Stereotype Pixies" do not provide the clear markers of the author's intent and this ambiguity can easily be exploited (Gogan 2009). As I argue later, I believe that there are sufficient markers. 
But, before defending that intuition, I will address Chappelle's argument from avoiding harms directly.

\subsection{Uncaused Harms}

It is widely assumed that you are responsible only for the harms you cause. You would rightly be surprised to discover that you were being blamed for harms that occurred before your birth, are on the other side of the world, or are otherwise not the result of your actions. In addition to actually causing the harm, intent to cause harm is also generally considered essential in assigning moral blame. If you did not mean to cause harm, were unaware of what you were doing, or if you reasonably believed that what you were doing was right, then you are not responsible-or at least you are less deserving of punishment. However, wicked intent is not always required. In the law, there is such a thing as strict liability, in which a person must compensate another person they have harmed if there was no malicious intent or even an awareness that what they have done is against the law (mens rea). If you are caught speeding, it does not matter why you were driving too fast or if you were aware of the speed limit. So too for statutory rape, in which it does not matter if the offender was aware of the victim's age or if they intended to do harm. In both cases, being the cause of the harm is sufficient to make a person legally responsible.

Admittedly, legality and morality are not the same in a liberal society, but strict liability provides a useful analogy. We might imagine a strict moral liability, in which the intent simply does not matter when assigning moral responsibility. ${ }^{13}$ All that matters is that a person caused another to be harmed. Chappelle's argument that he had a moral responsibility to refrain from making the Black Pixie sketch (and other racially charged humor) because of the harmful consequences, despite the absence of malicious intent, then seems to rely on strict moral liability. The strictest and simplest formulation of Chappelle's argument is then: If your action causes harm to others-the reinforcement of racist beliefs and attitudes and promotion of racist acts, in this case- then you have an overriding moral obligation not to do it.

However, strictly speaking, Chappelle would not have caused the harms he feared. Let us imagine for the sake of argument that Chappelle's comedy was a necessary condition for the eventual harm. In other words, if the racist audience

13 There is not an extensive literature on strict moral liability, unlike with legal liability, but two exceptions are: Capes (forthcoming) and Rosen 2015. 
member had not seen it, they would not have acted immorally. But, even if we grant this assumption that his actions were a necessary condition, it is not enough to establish responsibility. When there is intervening agency by another person, that person has initiated a new causal chain, and they are responsible for what follows. For example, if you were to sell someone your car and then they crashed into someone else's home as they were driving away, you would not be responsible. Rather, the driver is, despite the fact that your providing the car was a necessary condition for the eventual harm. That others may crash cars does not impose a moral obligation not to sell them.

The analogy to Chappelle's jokes is obvious. By writing, performing, and airing the sketch, Chappelle would not directly harm anyone, though it is certainly possible that people would be offended. Chappelle's fear was that he was reinforcing racist stereotypes among those who did not get his morally right intention, those who did not get the joke. But for that harm to come about, misunderstanding bigots had to intervene. They initiate a new causal chain and are responsible for the consequences. Even if one could argue that Chappelle's jokes provided a permission structure within which bigots felt free to act upon their bigotry, the responsibility rests on them.

\subsection{Chappelle's Possible Negligence}

But perhaps direct causation is too narrow of a standard. People are sometimes morally responsible for the harms that, strictly speaking, they did not cause. We could accept that Chappelle was not strictly morally responsible, but still believe that he is morally responsible for his jokes' harm because he was being negligent. A person acts negligently when they should have been aware of the substantial and unjustifiable risk of their actions, as their failure to perceive the risk grossly deviates from what a reasonable person would see. They did not foresee harm, but they should have. This is a murkier standard than simply asking whether Chappelle caused the eventual harm. Again making an analogy to legal concepts, consider the classic case of Palsgraf v. Long Island Railroad, in which a railroad employee pushed a salesman to assist him onto a train, unwittingly causing the salesman to drop a suitcase full of fireworks onto the tracks, causing them to explode, causing a scale on the platform to fall over, causing injury to poor Mrs. Palsgraf. The Court ruled that Long Island Railroad was not liable because the harm was not a reasonably foreseeable result of the original act. This has come to be known as the "zone of danger test," which sets a limit to legal liability. 
Were innocent people within the "zone of danger" of Chappelle's racial humor? Would he have been negligent if he had aired the Black Pixie sketch, leaving him responsible for future harms and imposing a moral obligation to refrain from such comedy? While a person is neither morally responsible nor liable if they sell their car to someone who crashes it, they are arguably responsible if they instead sold their gun without conducting any sort of background check. This is especially true if they have reason to believe that one of their customers will use it to cause harm, either because they were vocal about their desire to murder someone or simply because, if someone sells enough guns, a reasonable person knows that one will be used immorally. To conclude that Chappelle was being negligent, we must believe that the Black Pixie sketch is more like a gun than a car. It must be the sort of thing that poses such a substantial risk of harm that a reasonable person would be negligent to leave it lying around.

But jokes are not. Despite what any dwindling number of pure adherents to the superiority theory of humor might believe, jokes are not free-floating tools of aggression. ${ }^{14}$ For the harm to result, the audience must completely miss the joke, believe that the joke gives them permission to be bigoted, and then act immorally. If anything, Chappelle's humor was analogous to neither a car nor a gun but an anti-violence educational doll that was used, against its intended and predictable purpose, to bludgeon someone.

Further, even a gun seller is spared responsibility if they take reasonable precautions to ensure that the gun will not be used to harm innocents. Analogously, a comedian who makes a good-faith effort to ensure that they do not harm others, directly or indirectly, has then not been negligent. The sketch would have been aired in the context of a comedy show on a comedy network by a racially progressive, African-American comedian. Jokes told by a comedian and set in the context of a comedy show, a comedy club, or a comedy album may reasonably be expected to be taken as humorous rather than serious, as ironic rather than literal. Given that his jokes were clearly set within a play-frame, reasonable precautions were taken and Chappelle did not display recklessness and disregard for others' wellbeing. This was not akin to selling guns without background checks or to firing bullets into the air without regard for where they would land. While a genuinely racist joke may grant bigots permission to be bigots, Chappelle's humor does not, whatever their misunderstanding might be. It is not an incitement to violence, or even a vague conspiracy mongering, which would be moral-

14 The superiority theory of humor, which dominated the Western understanding of humor for millennia, holds that we laugh when we suddenly become aware of our superiority to others (or ourselves at an earlier time). Laughter is then mockery, ridicule, laughing at. 
ly culpable speech. And, if one claims that a joke told even under these circumstances makes the comedian morally responsible for any harm, then far too many morally permissible acts will get caught in the net. Such strict moral liability, which ignores all concern for intention or character, ignores a host of our basic moral intuitions regarding what makes for moral blame.

\subsection{Weighing the Benefits Too}

But let us concede that, despite the absence of malice, the looseness of the causation, and the presence of reasonable precautions to prevent misuse of his comedy, Chappelle's humor might result in foreseeable harms. For the sake of argument, we could claim that this is sufficient to impose a prima facie moral obligation on him not to tell racially charged jokes. All other things being equal, we have a moral obligation not to be complicit in systemic wrongs like racism, even indirectly and in an attenuated way-but does that obligation override all other considerations? Specifically, while it is certainly appropriate to consider the predictable harms of his racial humor when evaluating its morality, no consequentialist ethics (of which Chappelle's anti-harm argument is one variety) should ignore the benefits, and it is not clear to me that his racial comedy does more harm than good.

The position that a comedian has a moral obligation not to make jokes that might be taken-or inevitably will be taken-the wrong way and therefore causes unintended harms ignores all of the good that comedy can do. The benefits of satire and humor as a form of racial critique and resistance are significant. While racial humor has been used as a means of social control by the powers that be, satire generally, and the tradition of African-American humor in particular, have long served as a weapon in the hands of otherwise socially marginal people (Watkins 1994). Chappelle's early jokes about how black men must fear getting shot by the police only to have crack "sprinkled" on top of them, how every black American is a registered paralegal because of their history with

the judicial system, and the way that whiteness protects people from both of these, are excellent examples of politically charged humor that lets his typically mixed-race audiences understand one aspect of race in contemporary Americaall while showing great craft and making them laugh. And Chappelle is only the inheritor of a long tradition of resistant African-American humor, both covert and overt, that appeals to both socially dominant audiences and marginal ones. It is a means to explore the legacy of racism and to develop solidarity among marginal groups and with their allies. At the same time, predominantly white audiences waiting for The Daily Show were being educated by Chappelle 
an hour before. Ironic use of stereotypes is then a means of resistance to those stereotypes themselves.

Of course, one could object that it is possible to make humor that does not take the risks Chappelle's does. If a comedian wants to avoid misunderstanding and the possible harms that come with it, then they can unambiguously joke in a way that is both funny and politically progressive. However, that is very unlikely. Comedy involves a delicate negotiation between a comedian and audience that can always break down. Any humor that is so unambiguous as to be impossible or at least extremely unlikely to misinterpret will be either bland or propaganda. When the moral or political message dominates over amusement, the humor will suffer. Laughter becomes "clapter," a term invented by Saturday Night Live head writers Seth Meyers and Tina Fey to describe what audiences do when they show agreement with the message rather than amusement. This is not to say that amusement must always be our overriding goal in life, but it is in comedy.

As noted above, there is no satire, no racially-critical humor, no gender-critical humor, or otherwise resistant humor that will not be misinterpreted by someone, and frequently by bigots. While The Colbert Report and All In The Family may seem to be indisputably obvious satires of right-wing bloviating, they have been proven to be vulnerable to complete misunderstanding by prejudiced audiences. Humor inevitably involves a complex process of negotiation between a comedian and audience over whether to play by the rules of comedic playframe or by those of everyday, serious communication, and it often breaks down. Even in cases where the audience agrees to play along, there is an inescapable ambiguity. Humor can and will be misunderstood. No attempt at clarity of moral purpose is fool-proof, given the preponderance of fools in the world. Therefore, if the sheer fact that Chappelle's humor may be misinterpreted as giving permission to be racist is sufficient reason to stop making those jokes, then we should all start enjoying puns and knock-knock jokes much more than we currently do. At the least, we would have to conclude that it was morally wrong for Mark Twain to write Huckleberry Finn or for Jonathan Swift to write A Modest Proposal. Applying a "foreseeable harms of humor" standard then results in significant moral, political, and aesthetic losses that must be factored in and that likely outweigh the harms.

\subsection{When Bigotry Restricts Autonomy}

But again, let us say that a person has not been persuaded by the previous arguments that Chappelle did not directly cause harm, that he was not being negligent, or that the benefits of his humor outweigh the harms. In that case, let us 
return to the earlier intuition that another's intervening immorality and the harms that result from it should not transform otherwise innocent or good actions into bad ones. Is the habit of saving money rendered immoral if those funds are then used by bad people for nefarious purposes? It wouldn't seem so, even if it is reasonable to assume that many bad people work in finance and some will inevitably use funds to enrich themselves, buy off politicians, or exploit mortgage holders. Sadly, this assumption is true even if you go to great lengths to save in a socially responsible manner. Or a person may have the habit of being kind and supportive of others, which may be misunderstood as toying with people's affections. A person may have an honest character, but that might lead others to think that a cruel frankness is acceptable because they didn't understand or are morally insensitive. Would others' intellectual and moral failings convert the virtues of moderation, kindness, and honesty into vices?

Defending this intuition involves a final analogy from legal philosophy. In this case, the area is anti-discrimination law. Richard Mohr, a fierce defender of gay rights, makes a case against well-meaning discrimination. While the matter at hand is not a case of unjustified discrimination against Chappelle and has nothing to do with LGBT rights, allow me to explain how Mohr's analysis helps.

What Mohr has in mind are the supposedly good faith arguments by those who would exclude LGBT people from serving in the armed forces, deny them teaching positions, or prevent them from having custody of their children. The person imposing such discrimination makes it clear that they bear no ill will toward LGBT people, but that they must prevent a harm resulting from our prejudiced society. If gays are allowed to serve openly in the armed forces, unit cohesion and moral will weaken while those LGBT soldiers will be at risk of harm from their fellow soldiers. An openly gay teacher might encourage gay students to come out of the closet, exposing them to prejudice and abuse. If LGBT people are allowed to have custody of children, then those children will be bullied. In each case, those denying equality before the law or in employment argue that there is a predictable harm that will come to innocents, so the law must lamentably discriminate against people who are doing nothing wrong.

Mohr has little time for such arguments, as none address the true source of the problem: the bigots who would do harm. It is the bigoted soldiers, parents, and bullies who bear the moral responsibility. Supposedly kind acts of discrimination only perpetuate the harms that befall innocent LGBT people by codifying social prejudice in law and policy. Instead, bigoted soldiers and parents should be punished. In response, Mohr proposes the Wilde Principle: "[S]imply citing the current existence of prejudice, bigotry, or discrimination in a society against some group or citing the obvious consequences of such prejudice, bigotry, or dis- 
crimination can never constitute a good reason for trying to establish a good faith discrimination against that group” (Mohr 1988, 193). ${ }^{15}$ Inclusion in the armed forces, hiring decisions, and parental custody should be determined by bona fide occupational qualifications, not the risk that bigoted people will lash out at the innocent.

In Chappelle's case, we may appeal to a modified version of the Wilde Principle, but one that appeals to the same intuition that we have misplaced the responsibility. As a general principle, we should not cite others' bigotry or the predictable harms of that bigotry as good reason to justify limiting the otherwise good acts of blameless people. As Mohr puts it in another context, "threats of the violent are allowed to morally ground restrictions on the liberty of the wholly innocent" (Mohr 1988, 194). While the moral condemnation of a comedy sketch pales in comparison to the injustice of denying employment or denying a parent custody of their child, the principle is the same. If not for the bigotry of certain members of his audience, Chappelle would have done nothing wrong. It is morally wrong to impose obligations by appealing to explicit or implicit threats made by bigots. ${ }^{16}$

Of course, there are limits. It is possible to imagine scenarios in which another's immorality may require that I refrain from doing an otherwise good action. While we might want to act as if we are in ideal world in which everyone else acts rightly, our world is obviously not ideal and that places certain prudential -and possibly moral-obligations on moral agents. Consider Bernard Williams's famous thought-experiment from Against Utilitarianism of Jim and Pablo in the jungle (Williams 1973). Pablo, a cruel man, is going to shoot twenty innocent indigenous people, but he is willing to kill one and let the others go if Jim agrees to be the one who pulls the trigger. It would seem that, from utilitarian considerations, Jim has an obligation to set aside his strong aversion to murder and do it so the others will be spared. As such, his otherwise virtuous action-not killing the innocent-might be rendered immoral by Pablo's cruelty. Similarly, Chappelle's humorous and educative exploitation of racial stereotypes might be made immoral because bigots' intellectual and moral vices would put innocents at risk of harm.

15 See Chapter 5 passim. For an earlier version of his argument, see Mohr 1982.

16 Chappelle himself does not consider another way that his humor may cause harm. A member of the racially stereotyped community may feel humiliated by the use of the Sambo (and other) stereotypes. The harm is then not mediated by the immoral character and/or actions of a bigot. Since I am evaluating Chappelle's stated arguments for leaving comedy here, I have not addressed this possibility further. 
But Williams used this example to draw out a morally relevant consideration that was missing from Utilitarian moral calculations: the fact that it matters who the author of an evil action is. Even if we concede that Jim or Chappelle has a moral obligation to refrain from doing the facially good thing, we may still object that this imposition of this "duty" is itself immoral. It is to impose a plan for someone's life onto them by threat of greater harm. It constrains another's moral autonomy through violence. This is not something that can easily be dismissed, even if we come to the utilitarian conclusion that the overall right thing to do is to submit. Though we may believe that Jim should have pulled the trigger to spare the other nineteen innocents, we would likely forgive him if he said that he simply could not bring himself to do it. Similarly, we would likely forgive Chappelle if he were to admit that, while he knows that his comedy will be misinterpreted by some and bring about some bad results, he would feel violated if he were forced to stop making comedy which is otherwise morally progressive and so he has decided to keep doing it. This indicates that he was not under an obvious and overriding obligation to avoid racial humor.

Further, much of the analysis of the ethics of humor focuses on the ethical obligations of those who laugh, whether it is the comedian or the audience. However, there are moral obligations on those who fail to get the joke as well. While Chappelle's stagehand may have missed the humor, he was under a prima facie obligation to accept the invitation to see Chappelle's use of racial stereotypes as ironic and humorous (in addition to their obvious, prior moral obligation not to have racist attitudes in the first place). There is a general obligation to accept the rules of communication proposed by those we are speaking with, assuming we do not have a compelling reason not to. Refusing to be playful when we have been invited to, and when we have no compelling reason not to, is to be humorless and unfriendly. Further, by not accepting this invitation, the stagehand was taking Chappelle's use of the Sambo stereotype literally, which is to attribute morally offensive beliefs to Chappelle and is itself prima facie wrong. His failure to live up to his obligations does not impose an obligation on Chappelle who was otherwise acting morally.

To argue otherwise entails that the least moral, least understanding person in the audience sets the standard of moral rightness for others. The most or least easily offended person does not set the standard for all. When determining whether an act is immoral, it is not appropriate to depend on the judgment of just anyone, but upon that of a reasonable person of a reasonable level of moral sensitivity. Of course, what level is reasonable is open to debate. What strikes one person as a playful commentary on race may strike another as a grievous and insensitive put-down of an entire people. There is room for reasonable disagreement over whether a joke was in poor taste or even profoundly of- 
fensive. But certainly, when making these determinations, we should not rely upon the judgment of an objectively terrible bigot. If the anonymous stagehand who played the central role in Chappelle's decision to take a leave from comedy was, in fact, a racist, then we should not value his judgment of what the joke was about or whether it was funny. Nor should we base our own decisions of what is right or obligatory on how it will be received by them. By shifting responsibility onto Chappelle, we have given the bigot a veto over what comedy is morally permissible.

\section{Conclusion}

Therefore, while the use of racial humor is risky because of the unintended but predictable consequences, that risk does not impose a moral obligation on the comedian and did not require Dave Chappelle to leave stand-up. Of course, he had every legal and moral right to decide whether he wanted to continue making art that might inadvertently harm those causes he believes in-it may even be admirable-but he was not obliged to do so. Nevertheless, had he stayed to complete the next season of his eponymous show, or continued to perform standup, he would not have violated a compelling moral obligation. And, if this analysis is correct, then simply noting that comedy can or will have negative consequences does not establish that the comedy is immoral.

\section{References}

Amarasingam, Amaranth. 2009. "Gramsci, Selling Out, and the Politics of Race Loyalty." In The Comedy of Dave Chappelle: Critical Essays, edited by K.A. Wisniewski, 115-26. Jefferson: McFarland and Company.

Capes, Justin. Forthcoming. "Strict Moral Liability." Social Philosophy and Policy.

De Sousa, Ronald. 1987. "When is it Wrong to Laugh?” In The Philosophy of Laughter and Humor, edited by John Morreall, 226-49. Albany: State University of New York Press.

Farley, Christopher. 2005. “Dave Speaks.” Time, May 14, 2005.

Ferguson, Mark, and Thomas Ford. 2008. "Disparagement humor: A Theoretical and Empirical Review of Psychoanalytic, Superiority, and Social Identity Theories." Humor: International Journal of Humor Research 21(3): 283-312.

Ford, Thomas E., Kyle Richardson, and Whitney Petit. 2015. “Disparagement Humor and Prejudice: Contemporary Theory and Research.” Humor: International Journal of Humor Research 28(2): 171-86.

Gogan, Brian. 2009. “Laughing Whiteness: Pixies, Parody, and Perspectives.” In The Comedy of Dave Chappelle: Critical Essays, edited by K.A. Wisniewski, 72-85. Jefferson: McFarland and Company. 
Inside the Actor's Studio. 2006. “Dave Chappelle.” February 12, 2006.

Krefting, Rebecca. 2014. All Joking Aside: American Humor and Its Discontents. Baltimore: Johns Hopkins University Press.

LaMarre, Heather L., Kristen D. Landreville, and Michael Beam. 2009. "The Irony of Satire: Political Ideology and the Motivation to See What You Want to See in The Colbert Report." The International Journal of Press/Politics 14(2): 212-31.

Lee, Katherine. 2009. "When Keeping It Real Goes Wrong: Subversions of Racial Authenticity" in The Comedy of Dave Chappelle: Critical Essays, edited by K.A. Wisniewski, 127-38. Jefferson: McFarland and Company.

Mohr, Richard. 1982. "Gay Rights." Social Theory and Practice 8: 31-41.

Mohr, Richard. 1988. Gays/Justice: A Study of Ethics, Society, and Law. New York: Columbia University Press.

Oprah Winfrey Show. 2006. “Chappelle’s Story.” February 3, 2006.

Rosen, Gideon. 2015. "The Alethic Conception of Moral Responsibility." In The Nature of Moral Responsibility: New Essays, edited by Randolph Clarke, Michael McKenna, and Angela M. Smith, 65-88. New York: Oxford University Press.

Saraiya, Sonia. 2017. "Comedian Hari Kondabolu on Making The Problem with Apu." Variety.com. November 17, 2017. https://variety.com/2017/tv/news/comedian-hari-konda bolu-apu-the-simpsons-hank-azaria-1202618837/.

Silverman, Sarah. 2010. The Bedwetter: Stories of Courage, Redemption, and Pee. New York: HarperCollins Publishers.

Vidmar, Neal, and Milton Rokeach. 1974. "Archie Bunker's Bigotry." Journal of Communication 24(1): $36-47$.

Watkins, Mel. 1994. On the Real Side. New York: Simon and Schuster.

Williams, Bernard. 1973. "A Critique of Utilitarianism." In Utilitarianism: For and Against. Cambridge: Cambridge University Press.

Yates, Kimberley. 2009. "When Keeping It Real Goes Right" In The Comedy of Dave Chappelle: Critical Essays, edited by K.A. Wisniewski, 139-55. Jefferson: McFarland and Company.

Zinoman, Jason. 2017. Searching for Dave Chappelle. Amazon Digital Services. Kindle Edition. Zinoman, Jason. 2019. "His Punch Lines Cross Moral Lines. Anthony Jeselnik Gets Away with It.” New York Times, April 30, 2019. https://www.nytimes.com/2019/04/30/arts/tele vision/anthony-jeselnik-netflix.html. 